waarden voor de ontwikkeling van den parasiet ongunstig zijn; want het zal in de praktijk wel nooit uitvoerbaar blijken, dor vruchtwisseling of andere maatregelen den grond in die mate te zuiveren, dat, indien de ontwikkelingsvoorwarden voor den parasiet gunstig zijn, het aantal niet in korten tijl weer dusdanig kan zijn vermeerderl, dat de: ergste gevolgen kunnen worden verwacht.

Aan de andere zijde hebben practici mij wel verteld, dat zij vroeger van de aaltjesziekte in hum land last gehad hadden, maar dat de kwal, zonder het bew ust toepassen vam bestrijdingsmaatregelen, weer verdwenen was, terwijl vam den overwegenden roggebonw door hen niet was afgezien.

Wageningen, April $1906 . \quad$ H. Mayer Gmelin.

\title{
YORTE DEDEOEELIMGEN,
}

I. - Bestrijding van de pokzickte der perebladeren. -In de a Erfurter Führer im Gartembau s von 18 Sept. $190 t$ komt een opstel over de pokziekte der perebladeren en hare bestrijding voor, en wel van de hand van D) $^{r}$. L. Reh. -Over de ziekte zelve zal ik hier niet verder uitweiden; zij is tegenwoordig hier to lande vrij algemeen bekend; en ten overvloede verwijs ik naar het ten vorigen jare verschenen werk : Ritzema Bas, a Ziekten en Beschadigingen der Ooftboomen $\triangleright, \mathrm{IV}^{\mathrm{e}}$ deeltje, bl. 80-82. Daar zijn ook de bestrijdingsmiddelen angegeven, en onder deze het bespuiten der pereboomen gedurende den winter met een petroleumemulsie. Ik heb daarbij do opmerking gemaakt, dat ik wel eenigszins aan de goede uitwerking van dit mildel twijfel.Juist dáárom wil ik hier weergeven wat $D^{r}$. lieh omtrent de bestrijding met potroleumemulsio angeoft. Wen zeker 
middel ter bestrijding is het bespuiten der aangetaste boomen met eene petroleumèmulsie, die tusschen de knopschubben doordringt en de galmijten doodt. De uitvinder dezer methode, Prof. Slingerland in Ithaca (N. Amerika) beschrijft de vervaardiging der emulsie als volgt: 1 pond (1/2 K.G.) groene zeep wordt in 6 Liter kokend water volledig opgelost. Bij de nog heete oplossing giet men onder voortdurend omroeren met een schuimspaan 12 Liter petroleum, en roert zoo lang (minstens 5 minuten lang) tot de massa een gelijkmatig schuim vormt. Deze kan nu dadelijk worden gebruikt, maar zij kan ook op eene koele, donkere plaats worden bewaard, tot de tijd gekomen is om ze te gebruiken. Vóór 't gebruik echter' moet eerst iedere hoeveelheid, die men er uit neemt, met drie à vier deelen kokend water worden opgelost, en vervolgens met 5 à 7 maal de hoeveelheid koud regenwater worden verdund. Dan wordt de vloeistof met behulp van een pulverisateur over de boomen gespoten, vooral over de eindknoppen, waarin altijd de meeste mijten zitten.

Deze bestrijdingsmethode mag alleen in den winter worden toegepast, het best in Februari, op een' vorstvrijen, zonnigen dag. De uitwerking moet zoo voortreffelijk zijn, dat Prof. Slingerland zegt: a Bij al onze werkzaamheden met bestrijdingsmidelen tegen schadelijke insekten hebben wij nooit zoo'n prachtig resultaat gehad als bij deze methode van bestrijding der pokziekte met behulp van petroleumémulsier $\%$.

Ik wil er nog even op wijzen, dat men bij de bereiding van doze émulsie vooral brandgevaar moet vermijden dioor de warme zeepoplassing natuurlijk van 't vuur to nemen vóór men er petroleum bij mengt.

J. R. B.

II. - Nederlandsche Vlinders, beschreven en afgebeeld 